
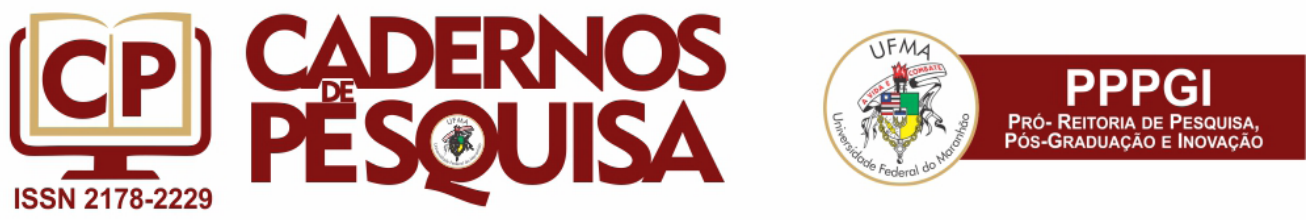

\title{
POLÍTICAS PÚBLICAS, EXPANSÃO DO ENSINO SUPERIOR PRIVADO LUCRATIVO E FINANCEIRIZAÇÃO DO CAPITAL NO BRASIL: o caso da Kroton Educacional S.A.
}

\author{
PUBLIC POLICIES, EXPANSION OF PRIVATE HIGHER EDUCATION AND \\ FINANCING OF CAPITAL IN BRAZIL: the case of Kroton Educacional S.A. \\ POLÍTICAS PÚBLICAS, EXPANSIÓN DE LA ENSEÑANZA \\ SUPERIOR PRIVADA LUCRATIVA Y FINANCIERIZACIÓN DEL \\ CAPITAL EN BRASIL: el caso de Kroton Educacional S.A.
}

\author{
Fábio Luciano Oliveira Costa1 \\ Pós doutorado em Educação pela Universidade Federal de Santa Catarina (UFSC). \\ Florianópolis - SC, Brasil. \\ costalofabio1@gmail.com
}

\begin{abstract}
Resumo
Este texto tem como objetivo central expor o estudo desenvolvido sobre a Kroton Educacional S.A., de 2007 a 2012, tendo em conta a notável expansão do ensino superior no setor privado com finalidades lucrativas, nas quase duas últimas décadas, imersa num processo mais amplo de financeirização do capital, que encontrou maiores incentivos a partir do final dos anos de 1960, em especial, nos países centrais. A escolha do referencial de análise se deu pela abordagem qualitativa, por meio do estudo da legislação pertinente ao assunto, da bibliografia associada ao tema, além dos exercícios sociais da companhia, no período delimitado. Observou-se como as novas estratégias de gestão corporativa da empresa, bem como certos incentivos governamentais permitiram seu importante crescimento. Com as metas da Kroton Educacional S.A. para sua valorização em curto prazo, sobretudo no mercado acionário, estreitaram-se os laços entre educação e mercadoria.
\end{abstract}

Palavras-chave: Financeirização do capital. Kroton Educacional S.A. Ensino Superior Privado. Mercadoria. Lucro.

\begin{abstract}
The main objective of this text is to outline the study carried out on Kroton Educacional S.A. from 2007 to 2012, taking into account the remarkable expansion of higher education in the private sector for profit in the last two decades, immersed in a broader process of financialization of capital, which found greater incentives from the late 1960s, especially in the central countries. The choice of analytical reference was based on the qualitative approach, through the study of relevant legislation, the bibliography associated with the topic, and the company's fiscal years, within the defined period. It was observed how the company's new corporate management strategies as well as certain government incentives allowed its important growth. With the goals of Kroton Educacional S.A. for its short-term appreciation, especially in the stock market, the ties between education and merchandise were tightened.
\end{abstract}

Keywords: financialization of capital. Kroton Educacional S.A. Private Higher Education. Merchandise. Profit.

\section{Resumen}

Este texto tiene como objetivo central exponer el estudio desarrollado sobre Kroton Educacional S.A., de 2007 a 2012, teniendo en cuenta la notable expansión de la enseñanza superior en el sector privado con fines lucrativos, en las casi dos últimas décadas, inmersa en un proceso más amplio de financierización del capital, que encontró mayores incentivos a finales de los años 1960, especialmente en los países centrales. La elección del referencial de análisis se dio por el abordaje cualitativo, por medio del estudio de la legislación pertinente al asunto, de la bibliografía asociada al tema, además de los ejercicios sociales de

1 O autor agradece 0 apoio financeiro do CNPq e da FAPESP.

Artigo recebido em junho 2017. Aprovado em novembro de 2018.

Cad. Pesq., São Luís, v. 25, n. 4, out./dez. 2018. 
la compañía, en el período delimitado. Se observó cómo las nuevas estrategias de gestión corporativa de la empresa, así como ciertos incentivos gubernamentales, permitieron su importante crecimiento. Con las metas de Kroton Educacional S.A. para su valorización a corto plazo, sobre todo en el mercado accionario, se estrecharon los lazos entre educación y mercancía.

Palabras clave: Financierización del capital. Kroton Educacional S.A. Enseñanza Superior Privada. Mercancía. Ganancia.

\section{INTRODUÇÃO}

O objetivo principal deste trabalho consistiu na análise da financeirização do capital no ensino superior do setor privado com fins lucrativos ${ }^{2}$ no Brasil, por meio do estudo da Kroton Educacional S.A., no período de 2007 a 2012. Tal organização se encontra imersa num processo mais amplo de financeirização do capital na economia mundial, que recebeu fortes incentivos nas últimas quatro a cinco décadas, sobretudo nos países centrais, particularmente nos Estados Unidos e na Inglaterra.

Para viabilizar o estudo acerca da Kroton Educacional S.A., que atualmente conta, como uma de suas principais estratégias de gestão corporativa, com o capital aberto na Bolsa de Valores, Mercadorias e Futuros de São Paulo (BM\&FBovespa S.A.), buscouse, entre outros:

* Uma análise textual sobre os aspectos legislativos e a literatura especializada no tema, com a análise, principalmente, de livros; teses e dissertações acadêmicas; artigos publicados em revistas especializadas, sobretudo os educacionais; textos publicados nos meios de comunicação de massa (jornais, revistas e internet), associados ao ensino superior no Brasil, com o foco no setor privado, desde a segunda metade dos anos de 1990, até a segunda metade dos anos 2000;

* A seguir, mesmo que de modo simplificado, foram apresentadas algumas informações estatísticas sobre o ensino superior, principalmente no setor privado com finalidades lucrativas, de 1999 a 2009, e;

* Ainda, dados encontrados em algumas instituições, principalmente públicas no Brasil e dados operacionais e financeiros da Kroton Educacional S.A., no período de 2007 a 2012, sob a forma de gráficos, cujas referências foram retiradas do endereço eletrônico das suas relações com investidores. Destes procedimentos resultou um conjunto de elementos importantes, os quais foram submetidos ao escrutínio crítico.

Se, como colocou Severino (2001), a educação - assim como a política -, é constituída como uma prática intencional, que intervém nas relações sociais e contribui com a formação humana, então, há a necessidade da investigação de quais são alguns dos principais fios condutores desse processo, não só para poder elencá-los, mas também para as possíveis propostas de mudanças no conjunto social.

Assim, a análise crítica, que busca no contexto histórico a investigação sobre as multivariadas relações sociais de conflitos e contradições, pretende contribuir com a redução das discrepâncias nas relações sociais de poder, de forma que os interesses dos grupos dominantes possam não ser mais os interesses majoritariamente dominantes (SAVIANI, 2008).

Além desta introdução, o texto conta com mais quatro partes. Na primeira, abordase a legislação educacional e parte da literatura sobre o ensino superior, com o foco no setor privado, desde a segunda metade dos anos de 1990, até a segunda metade dos anos 2000.

Em seguida, tratam-se alguns dados associados à expansão do ensino superior no setor privado brasileiro, com destaque para o segmento particular, no período de 1999 até o ano de 2009.

\footnotetext{
Os termos, ensino superior do setor privado com fins lucrativos e ensino superior do setor privado particular são sinônimos, e a última definição, que veio com a Lei de Diretrizes e Bases da Educação Nacional (LDB), em 1996, permitiu pela primeira vez, que Instituições de Ensino Superior (IES), no país, pudessem se constituir, de fato e de direito, com finalidades lucrativas.
} 
Para a terceira, analisa-se a Kroton Educacional S.A., no período de 2007 a 2012 , com as suas novas estratégias de gestão corporativa, além dos seus expressivos crescimentos operacionais e financeiros. Por fim, as considerações finais apresentam alguns dos principais resultados do trabalho.

\section{A LEGISLAÇÃO PARA O ENSINO SUPERIOR NO BRASIL NOS ANOS DE 1990 E 2000}

A participação do Estado, sobretudo tendo em conta o Poder Executivo Federal, mediante instrumentos legislativos que Ihes são próprios, a exemplo dos decretos, das medidas provisórias, portarias, resoluções, ou de outros, como no caso das leis, que exigem a aprovação do Congresso Nacional, têm tido uma importante função na expansão do ensino superior do setor privado com finalidades lucrativas no Brasil, em especial, nas quase duas últimas décadas.

Apesar da ambiguidade conceitual, em consonância com o artigo 209 da Constituição Federal (CF) de 1988 (BRASIL, 1988), o ensino é livre - dentro de uma liberdade restrita -, à iniciativa privada, desde que cumpridas as determinações normativas da educação nacional e para o sistema de ensino; a autorização para o funcionamento e a avaliação colocadas pelo Poder Público; bem como a capacidade de autofinanciamento (com exceção do que expressou o artigo $213^{3}$ ).

No âmbito jurídico, a permissão para a constituição de IES com finalidades lucrativas ocorreu com a LDB/1996 (BRASIL, 1996), no governo de Fernando Henrique Cardoso (FHC - 1995-2002), que determinou a possibilidade da existência daquelas particulares, em sentido estrito, ainda que as mesmas existissem no Brasil há várias décadas ${ }^{4}$.

Por essa mesma lei, em seu artigo 16, o sistema federal de ensino foi compreendido como as IES mantidas pela União, as criadas e mantidas pelo setor privado, além dos órgãos federais de educação. A classificação das instituições de ensino superior ocorreu de acordo com duas categorias administrativas:

1) as públicas, que são criadas ou incorporadas, assim como mantidas e administradas pelo Poder Público (federal, estadual ou municipal), sob a forma de autarquias ou de fundações e;

2) privadas, mantidas e administradas por pessoas físicas ou jurídicas de direito privado, com recursos financeiros e proprietárias do patrimônio, conhecidas como mantenedoras, junto com outra pessoa jurídica que presta os serviços materiais e humanos em suas instalações, denominadas mantidas. No nível superior, em ambos os setores, o ensino deve conter diversos graus de abrangência ou especialização (arts. 19 e 45 da LDB/1996).

As IES do setor privado foram classificadas em particulares, criadas e mantidas por uma ou mais pessoa (s) física (s) ou jurídica (s) de direito privado, e desde que não se enquadrem na categoria sem fins lucrativos; comunitárias, criadas por uma ou mais pessoas jurídicas, sem fins lucrativos, o que envolve até mesmo cooperativas educacionais, e que tenham em sua mantenedora, representantes da comunidade; confessionais, criadas por grupos de pessoas físicas ou por uma ou mais pessoas jurídicas, sem fins lucrativos, que atendam a uma orientação confessional; e filantrópicas, conforme a lei (art. 20 da LDB/1996).

No artigo 77 da LDB/1996, em consonância com o artigo 213 da CF/1988, reafirmou-se a destinação de recursos públicos para as IES sem fins lucrativos e, no inciso VI do artigo 70, permitiu-se a concessão de bolsas de estudos para os alunos de escolas públicas e privadas.

\footnotetext{
Nesse artigo, ao ter que comprovar a sua finalidade não lucrativa, para as IES do setor privado comunitárias, confessionais e filantrópicas, mesmo que sem a explicitação jurídica, isso indicava a existência de IES do setor privado com finalidades lucrativas no país.

4 Oliveira (2017) e Sguissardi (2014) também ressaltaram o fato de a CF/1988 ter admitido, ainda que os termos não estivessem definitivamente claros, a possibilidade de IES com finalidades lucrativas. Assim, "segundo Moretti (2013), na década de 1910 houve uma mantenedora com fins lucrativos; duas na de 1950; 13 na de 1960; 24 na de 1970; e 10 na de 1980" (COSTA, 2016, p. 71).
} 
Chaves (2010) destacou a contribuição da LDB/1996 para o incentivo à mercantilização do ensino superior no país por permitir o funcionamento legal, pela primeira vez, de IES particulares com finalidades lucrativas. Já Neves (2002, p.139) classificou os empresários do setor como a "nova burguesia de serviços educacionais".

Os cursos e os programas para o ensino superior, presenciais ou a distância, passaram a comportar:

I) cursos sequenciais por campo de saber, com diferentes níveis de abrangência, para os candidatos que tenham concluído o ensino médio e conforme os requisitos das IES;

II) de graduação, para os candidatos com o ensino médio completo, os quais tenham sido classificados em processo seletivo;

III) de pós-graduação, como os cursos lato sensu - de aperfeiçoamento e de especialização -, e stricto sensu - de mestrado e de doutorado -, para portadores de diploma de curso superior e em atendimento aos critérios determinados pelas IES e;

IV) cursos de extensão, para os candidatos que se enquadrem nos requisitos impostos pelas IES (art. 44 da LDB/1996).

O credenciamento das IES, bem como a autorização e o reconhecimento de cursos começaram a ter prazo específico, o que não ocorria anteriormente, e a sua renovação deve passar por um processo avaliativo, de responsabilidade da União, ou dos demais entes federados, desde que mantenham as suas respectivas instituições.

À União coube a responsabilidade de garantir o processo nacional de avaliação das IES, mediante a cooperação dos sistemas com responsabilidade sobre esse nível de ensino, além de autorizar, reconhecer, credenciar, supervisionar e avaliar os cursos e estabelecimentos de ensino superior (incisos VIII e IX, art. $9^{\circ}$ da LDB/1996).

O ensino a distância, na LDB/1996, passou a receber o incentivo do Poder Público (em todos os níveis e modalidades de ensino), bem como o ensino continuado. Coube à União o credenciamento e a regulamentação dos requisitos para os exames e os registros dos diplomas associados aos cursos (art. 80).

A partir do Decreto $n^{\circ} 2.207 / 1997$ (BRASIL, 1997a), as questões associadas ao ensino superior do setor privado com fins lucrativos começaram a se tornar mais claras. As IES privadas, "a fim de ampliar os critérios objetivos para diferenciar as entidades mantenedoras, e, não mais, as instituições de ensino" (CARVALHO, 2011, p. 181), poderiam se constituir como pessoas jurídicas de direito privado, tais como sociedades civis, religiosas, pias, morais, científicas ou literárias, associações de utilidade pública ou fundações, além de sociedades mercantis.

Com esse decreto, a organização das IES do sistema federal de ensino foi classificada da seguinte forma: 1) universidades; 2) centros universitários; 3) faculdades integradas; 4) faculdades; e 5) institutos superiores ou escolas superiores ${ }^{5}$.

Ainda em 1997, o Decreto $n^{\circ} 2.306 / 1997$ (BRASIL, 1997b) revogou o Decreto $n^{\circ}$ 2.207. De acordo com Cunha (2007, p. 817):

As entidades com fins lucrativos livraram-se do prazo para alteração de seus estatutos, mas foi mantida a exigência de se submeterem à auditoria pelo poder público, devendo, ainda, publicarem anualmente demonstrações financeiras certificadas por auditores independentes.

Em 2001 foi a vez do Decreto $n^{\circ} 2.306 / 1997$ ser revogado pelo Decreto $n^{\circ}$ 3.860/2001 (BRASIL, 2001). A organização acadêmica que esteve subdividida em cinco incisos no Decreto $n^{\circ} 2.207 / 1997$ e no Decreto $n^{\circ} 2.306 / 1997$, passou a ter três no Decreto $n^{\circ} 3.860 / 2001$, sem alterar a tipologia ou a natureza das IES do sistema federal

Dessas IES, apenas as universidades são legalmente comprometidas com o ensino, a pesquisa e extensão, onde se podem encontrar, em especial no setor público, instituições de melhor qualidade. 
de ensino. A classificação foi definida como: 1) universidades; 2) centros universitários e 3) faculdades integradas, faculdades e institutos ou escolas superiores.

As mudanças de maior destaque no Decreto $n^{\circ} 3.860 / 2001$ corresponderam à avaliação dos cursos, dos programas e das IES, com a ampliação dos poderes do Ministério da Educação (MEC) nesse quesito, cujos processos de organização e execução ficaram a cargo do Instituto de Estudos e Pesquisas Educacionais Anísio Teixeira (INEP).

O Plano Nacional de Educação (PNE), Lei no 10.172/2001 (BRASIL, 2001a), propôs, entre outros, a institucionalização de um amplo e diversificado sistema de avaliação interna e externa nos níveis de ensino do setor público e do setor privado; o incentivo ao ensino a distância, ao tecnológico e sequencial; a elevação da autonomia das IES não universitárias, ainda que reforçasse o papel das universidades quanto ao ensino, à pesquisa e extensão; o incentivo à diversificação das IES; a flexibilidade nas diretrizes curriculares para os cursos de ensino superior; bem como o aumento dos cursos noturnos e o crescimento do crédito educativo.

Ainda em 2001 foi aprovada a Lei no 10.260 (BRASIL, 2001b), que instituiu o Fundo de Financiamento Estudantil (FIES), no Governo FHC. Esse Fundo, de natureza contábil, originalmente passou a ser destinado a estudantes regularmente matriculados em cursos superiores em IES do setor privado, desde que avaliados positivamente pelo MEC.

O valor máximo a ser financiado pelo FIES foi estipulado em 70,0\% (com as alterações posteriores passou a $100,0 \%$ ) dos encargos cobrados pela IES do setor privado ao estudante, que pode se candidatar a apenas um financiamento, para um curso superior (e desde que não tenha participado do anterior Programa de Crédito Educativo), pelo prazo não superior à duração regular da graduação (excepcionalmente dilatado por até mais um ano, por iniciativa da instituição), com juros fixados semestralmente pelo Conselho Monetário Nacional $(\mathrm{CMN})$, cuja aplicação será feita desde o início, até o final do contrato.

No governo de Luiz Inácio Lula da Silva (2003-2010), a regulação, supervisão e fiscalização do ensino superior no Brasil, em termos jurídicos, seguiram os caminhos do governo anterior. Quanto à avaliação, o Sistema Nacional de Avaliação da Educação Superior (SINAES) foi instituído pela Lei n 10.861, de 2004 (BRASIL, 2004), cujos objetivos consistiram na aplicação do processo nacional de avaliação das IES, dos cursos de graduação e do desempenho acadêmico dos estudantes, sob a responsabilidade do INEP.

Além disso, buscou estimular a melhoria da qualidade no ensino superior; orientar o crescimento de sua oferta; ou ainda aumentar a eficácia institucional e dos compromissos e das responsabilidades sociais das instituições, com a valorização de sua finalidade pública, o estabelecimento dos parâmetros democráticos, o respeito às diferenças e à diversidade, bem como a autonomia e a identidade institucional.

Por meio principalmente desse instrumento, mediante a apresentação dos seus resultados satisfatórios, o discurso sobre a qualidade do ensino superior no Brasil tem sido associado, ou não, às IES, tanto no setor público quanto no setor privado.

Como ressaltou Sguissardi (2009), o SINAES deixou a desejar, por exemplo, no que diz respeito à autonomia universitária, fora o fato da sua excessiva centralização nas mãos do Ministério da Educação (MEC). Já Barreyro e Rothen (2011) apontaram o caráter economicista dos recursos avaliativos usados nesse sistema, como o Conceito Preliminar de Cursos (CPC) e o Índice Geral de Cursos (IGC).

O Programa Universidade Para Todos (PROUNI) foi sancionado pela Lei $\mathrm{n}^{\circ}$ 11.096/2005 (BRASIL, 2005b), com a função principal de destinar bolsas de estudos integrais a brasileiros não portadores de curso superior, com renda per capita mensal de até um salário mínimo e meio, além de bolsas de estudos parciais (de $50,0 \%$ ou 
$25,0 \%$ ), para estudantes de cursos de graduação e sequenciais de formação específica (também não portadores de diploma de cursos superior), com renda familiar per capita de até três salários mínimos, em IES do setor privado, com ou sem finalidade lucrativa.

Conforme a Lei do PROUNI, os possíveis candidatos às bolsas correspondem aos estudantes que tenham cursado o Ensino Médio em escola pública ou em instituições privadas como bolsistas integrais; portadores de deficiência, nos termos da lei, e os autodeclarados negros e indígenas; além de professores da rede pública de Educação Básica, para os cursos de licenciatura, normal superior ou de pedagogia, independente de renda.

A participação das instituições privadas de ensino superior ocorre por meio da assinatura do termo de adesão, com vigência de 10 anos e renovável por igual período, pelo qual passa a oferecer, no mínimo, uma bolsa integral para o equivalente a 10,7 estudantes regularmente matriculados e pagantes, devidamente matriculados em seus respectivos cursos; ou, alternativamente, uma bolsa integral para cada 22 alunos matriculados e pagantes e a oferta de bolsas parciais, de forma que a soma dos benefícios concedidos atinja o equivalente a $8,5 \%$ da receita anual dos períodos letivos que já contam com bolsistas do PROUNI.

Caso haja o descumprimento dessas normas, a instituição deve restituir, como penalidade, o montante para cumprir os $8,5 \%$, mais o acréscimo de $20,0 \%$. Cabe destacar que, depois de duas avaliações insuficientes de algum curso no SINAES, com notas um ou dois, numa escala de um a cinco, o mesmo será excluído do PROUNI.

As IES particulares do setor privado passaram a contar com a isenção de tributos, no caso, o Imposto de Renda de Pessoa Jurídica (IRPJ), a Contribuição Social sobre o Lucro Líquido (CSLL), a Contribuição Social para Financiamento da Seguridade Social (COFINS) e a Contribuição para o Programa de Integração Social (PIS), quando da adesão ao PROUNI. Em relação às IES beneficentes de assistência social, devem oferecer anualmente, de forma gratuita, pelo menos $20,0 \%$ da receita bruta em bolsas de estudos.

De acordo com Catani, Hey e Gilioli (2006), o discurso da democratização do acesso ao ensino superior de baixo custo, com o PROUNI, acabou por camuflar a pressão exercida pelo setor privado de ensino superior em virtude do elevado número de vagas não preenchidas (a taxa foi de aproximadamente 49,5\%, em 2004, e de $55,8 \%$, em 2010, segundo dados do MEC), e da inadimplência no pagamento das mensalidades, sobretudo pelas dificuldades econômicas de arcar com essas despesas por parcela significativa da população brasileira, depois do ingresso em IES privadas.

Para o ensino a distância, com o Decreto n 5.622/2005 (BRASIL, 2005c), regulamentou-se o artigo 80 da LDB/1996. Essa modalidade de ensino passou por um expressivo processo de crescimento, sobretudo no setor privado, depois da segunda metade da primeira década do século XXI, embalada pelo discurso da ampliação da democratização para o acesso ao ensino superior, além da necessidade de crescimento para a formação de profissionais aptos ao exercício do magistério no ensino básico.

Em 2006, com o Decreto $n^{\circ} 5.773$, mais uma vez o Executivo Federal mexeu nas regras sobre a regulação, supervisão e avaliação das IES e dos cursos superiores de graduação e sequenciais no sistema federal de ensino.

A organização desse sistema continuou dividida em três categorias, ou seja, faculdades, centros universitários e universidades, tendo sido suprimidas nominalmente do texto legislativo as faculdades integradas e os institutos ou escolas superiores (mas equiparados às faculdades), conforme o Decreto $n^{0} 3.860 / 2001$.

O primeiro credenciamento de uma IES teria de ser feito como faculdade, por meio de autorização do MEC. Depois disso, passado o período de três anos, e atendidos os critérios mínimos de qualidade estabelecidos, poderia haver o pedido para a sua transformação em centro universitário ou em universidade, com as consequentes 
prerrogativas de autonomia. Em caso de parecer favorável, esse credenciamento inicial seria de três anos para o primeiro, e de cinco anos para a segunda.

Vários outros instrumentos legais foram aprovados no período, e os que foram citados fornecem uma ideia geral sobre a normatização do ensino superior no Brasil. Com isso, ainda que não se tenha almejado dar conta de todo o aspecto legal associado ao ensino superior, no período referenciado, constata-se como a legislação atuou para normatizar (desde os governos de FHC) e colocar regras mais claras para a sua atuação.

Na próxima seção, veremos alguns dados sobre o crescimento do ensino superior, em especial para as IES do setor privado com finalidades lucrativas, no que tange ao número de instituições, os cursos e as matrículas, no período de 1999 a 2009.

\section{ALGUNS DADOS SOBRE O ENSINO SUPERIOR NO BRASIL (1999-2009)}

Os números, no período de 1999 a $2009^{6}$, permitem-nos melhor compreender como os mecanismos legais contribuíram para a expansão do ensino superior, principalmente no setor privado com finalidades lucrativas, já que para as IES comunitárias, confessionais e filantrópicas, bem como para aquelas do setor público, ainda que possa ter havido crescimento numérico (o que deve ser verificado na consulta dos dados), suas participações, em relação ao total, de instituições, matrículas, cursos, entre outros, foram reduzidas em virtude da forte ampliação das IES particulares.

As pequenas melhorias havidas, por exemplo, na distribuição de renda no Brasil, ou as políticas de renúncia tributária e bolsas de estudo, possibilitaram a uma parcela da população, pagar as mensalidades.

Para o setor público, as IES obtiveram uma ampliação, de 1999 a 2009, de aproximadamente $27,6 \%$, quando passaram de 192 , no primeiro ano, para 245 , no segundo. No setor privado, para o mesmo período, as IES particulares cresceram aproximadamente $238,2 \%$, ao sair de 526 , para 1.779 ; enquanto as comunitárias, confessionais e filantrópicas conseguiram uma redução de $23,5 \%$, pois passaram de 379, para 290. (BRASIL, 2000, 2005a, 2010).

O Gráfico 1, abaixo, mostra os dados para as IES, segundo a categoria administrativa, de 1999 a 2009, em termos percentuais.

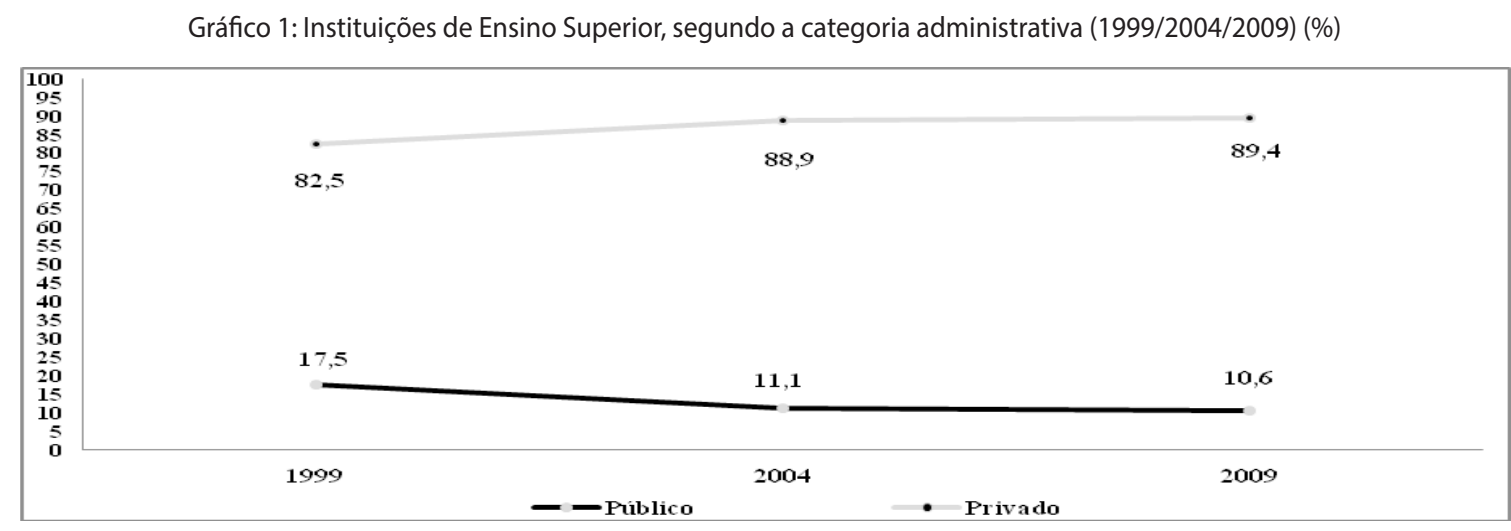

Fonte: Brasil (2000, 2005a, 2010)

Quanto aos cursos nas IES, no setor público, a expansão atingiu aproximadamente $135,5 \%$, de 1999 a 2009, quando saíram de 3.494, no primeiro ano, para 8.228, no segundo. Para o setor privado, também no mesmo período, em primeiro lugar para os cursos nas IES particulares, o aumento chegou a aproximadamente $510,0 \%$, pois saíram de 2.467, para 15.049; nas IES comunitárias, confessionais e filantrópicas, o crescimento foi de $56,0 \%$ (passaram de 2.917, para 4.550), ainda que o número de instituições tenha apresentado decréscimo.

\footnotetext{
De 1999 a 2009, nas Sinopses Estatísticas da Educação Superior, encontradas no endereço eletrônico do INEP, o setor privado foi classificado em duas categorias administrativas, ou seja, em particulares (com finalidades lucrativas), e em comunitárias, confessionais e filantrópicas (sem finalidades lucrativas). Contudo, antes e depois desse período, nos referidos documentos, a divisão foi suprimida, o que prejudica um melhor entendimento sobre o assunto.
} 
Pelo Gráfico 2, abaixo, pode-se observar a distribuição do número de cursos de graduação nas IES no país, segundo a categoria administrativa nas IES, de 1999 a 2009, em termos percentuais.

Gráfico 2: Número de cursos de graduação, segundo a categoria administrativa nas Instituições de Ensino Superior (1999/2004/2009) - (\%)

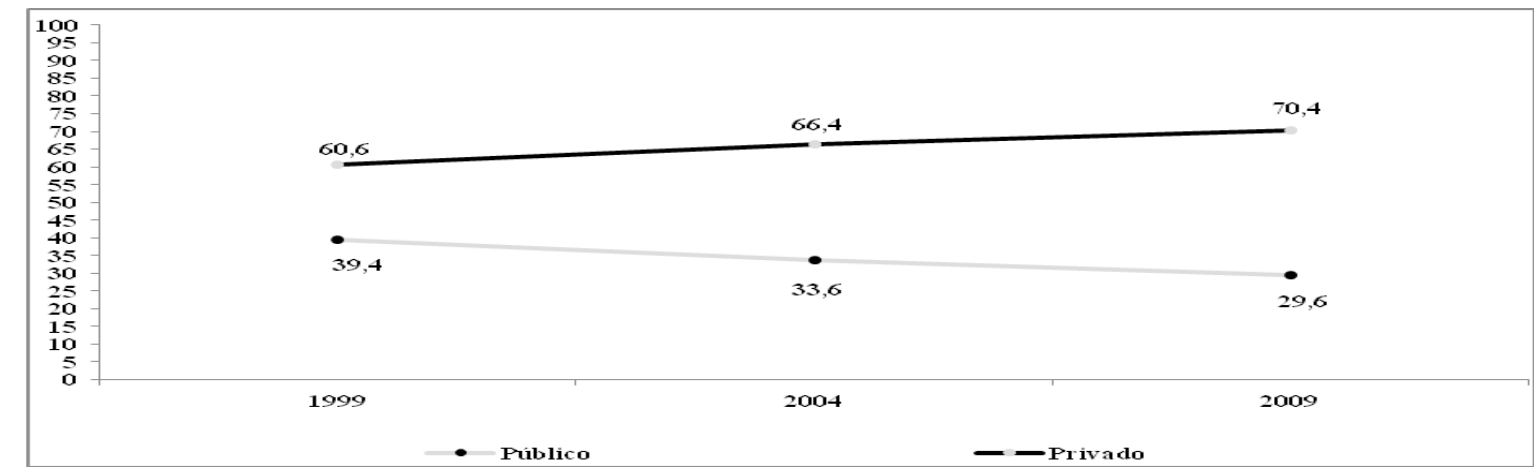

Fonte: Brasil (2000, 2005a, 2010).

Em relação às matrículas, nas IES do setor público, de 1999 a 2009, a expansão atingiu aproximadamente $62,4 \%$, pois passaram de 832.022 , no primeiro ano, para 1.351.168, no segundo. No setor privado, no mesmo período, para as IES particulares, o crescimento chegou a aproximadamente 345,2\% (passaram de 651.362, para 2.899.763); nas IES comunitárias, confessionais e filantrópicas houve queda de 2,4\% (saíram de 886.561, para 864.965).

Em termos percentuais, no Gráfico 3, abaixo, observa-se a distribuição do número de matrículas na graduação presencial, segundo a categoria administrativa, nas IES, de 1999 a 2009.

Gráfico 3: Número de matrículas na graduação presencial, segundo a categoria administrativa, nas Instituições de Ensino Superior (1999/2004/2009) - (\%)

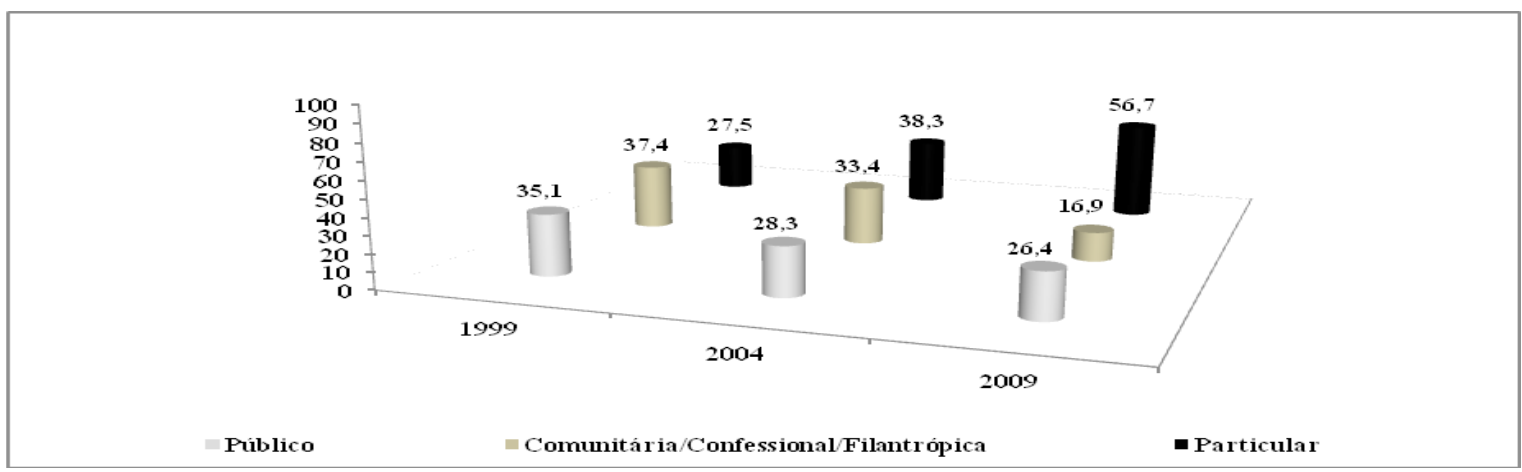

Fonte: Brasil (1999a, 2005a, 2009a).

Antes de passarmos adiante, convém abordar alguns dados sobre o ensino superior a distância, no período de 2000 a 2009, também de acordo com os dados do MEC, nas sinopses estatísticas da educação superior. Para a Kroton, essa modalidade de ensino se constituiu numa das principais alternativas para a expansão e a acumulação de capital conquistada nos últimos anos.

Na Tabela 1, abaixo, abordam-se o número de cursos; vagas oferecidas; candidatos inscritos; ingresso por vestibular e outros processos seletivos; matrículas; e concluintes nos cursos de graduação superior a distância, de 2000 a 2009. Nessa ordenação, o crescimento foi de aproximadamente $8.340,0 \%$; 24.187,9\%; 8.220,9\%; $6.188,4 \%$; $49.729,1 \%$; e $28.654,1 \%$. 
Tabela 1: Número de cursos, vagas oferecidas, candidatos inscritos, ingressos, matrículas e concluintes nos cursos de graduação a distância (2000/2004/2009)

\begin{tabular}{|c|c|c|c|}
\hline & 2000 & 2004 & 2009 \\
\hline Cursos & 10 & 107 & 844 \\
Vagas Oferecidas & 6.430 & 113.079 & 1.561 .715 \\
Candidatos Inscritos & 8.002 & 50.706 & 665.839 \\
Ingressos & 5.287 & 25.006 & 332.469 \\
Matrículas & 1.682 & 59.611 & 838.125 \\
Concluintes & 460 & 6.746 & 132.269 \\
\hline
\end{tabular}

Fonte: Brasil (2001d, 2005a, 2010)

Com esses dados ${ }^{7}$, iniciais, apenas para fornecer uma ideia sobre o que caracteriza tal crescimento, quando para ele se chamou a atenção, pode-se perceber o claro favorecimento no Brasil à ampliação das IES do setor privado com finalidades lucrativas, no período selecionado. No âmbito deste setor, uma das principais IES beneficiadas é a Kroton Educacional S.A., objeto da análise, a seguir.

\section{A KROTON EDUCACIONAL S.A.}

A profissionalização da gestão institucional das grandes empresas na área da educação, que se formaram nos últimos anos, tem sido a questão central para as suas administrações. A eficiência, a criação de valor, a consolidação da marca ou a qualidade, entre outros, constituíram-se como temas determinantes que não podem ficar de fora do cardápio dessas novas receitas corporativas.

Com a inserção de novos atores na gestão empresarial do segmento, tais como os fundos de investimentos; alguns bancos; os executivos (que nos últimos tempos passaram a ser chamados de Chief Executive Officer - CEO); ou os novos acionistas, algumas empresas educacionais começaram a criar as condições necessárias de arrecadação de maiores somas de capitais, em especial, no mercado financeiro.

Por isso é que essas empresas educacionais foram buscar a implantação de um modelo próprio de gestão semelhante ao das grandes corporações, além de uma mudança cultural na administração do negócio (POLIZEL; STEINBERG, 2013).

No sistema de governança corporativa, o cruzamento entre o que diz respeito à propriedade (principal), como no caso dos sócios, da (s) família (s), do Conselho de Administração, Conselho Fiscal, dos Comitês de Apoio e da Auditoria Independente, e a administração (controle), a exemplo dos diretores, da reitoria, das equipes que efetivam a organização e da Auditoria Interna, caracterizam a gestão empresarial e é nesse espaço que podem aparecer os principais impasses na condução do negócio.

Na reflexão de Guttmann (2008, p. 12), a "maximização do valor ao acionista" se tornou o objetivo central das companhias, sobretudo com a ascensão, nas últimas décadas, dos investidores institucionais que, muitas vezes, estabeleceram-se como os principais acionistas das empresas, a exemplo dos fundos de pensão, dos fundos mútuos e dos fundos de hedge, "que reúnem investidores menores para obter benefícios de escala (melhor diversificação, mais informações, menores custos de transações etc.)". Para Sguissardi (2014, p. 52):

O que preocupa de fato é o poderio econômico e político que estão adquirindo os bancos, fundos de investimento, grupos empresariais que oligopolizam o mercado educacional, em que, como já exposto, apenas 12 dessas "mantenedoras" são "proprietárias" de cerca de $40 \%$ das matriculas do setor privado-mercantil que atinge quase $70 \%$ do total de matriculas da ES do país. Somente a "Nova Kroton" - formada

Em Costa (2016), ainda longe de abarcar as possibilidades de tratamento dos dados das sinopses estatísticas da educação superior, a questão é mais bem trabalhada. 
pela fusão da Kroton e Anhanguera - estaria sendo avaliada em $\mathrm{R} \$ 22$ bilhões e totalizaria cerca de um milhão de matriculas (sem incluir as da educação básica).

Em meio aos ambientes competitivos de mercado, com a crescente "mundialização" do capital (CHESNAIS, 1996), a gestão corporativa das grandes companhias prioriza principalmente a valorização do capital em curto prazo (PLIHON, 1996), mediante os resultados periódicos trimestrais de desempenho da produtividade e dos preços das ações, subsidiados pelos direitos de propriedade, de forma que as aquisições e as fusões aparecem como as operações de negócio preferidas para o crescimento orgânico das empresas.

Sobre esse último ponto, vejamos alguns dados, no período de 2007 a 2013, para o número total de fusões e aquisições no ensino superior do setor privado brasileiro, que foi de 168 transações $^{8}$, conforme o Gráfico 4, abaixo, o que também envolve aquelas feitas pela Kroton.

Gráfico 4: Número total de fusões e aquisições no ensino superior do setor privado brasileiro (2007-2013)

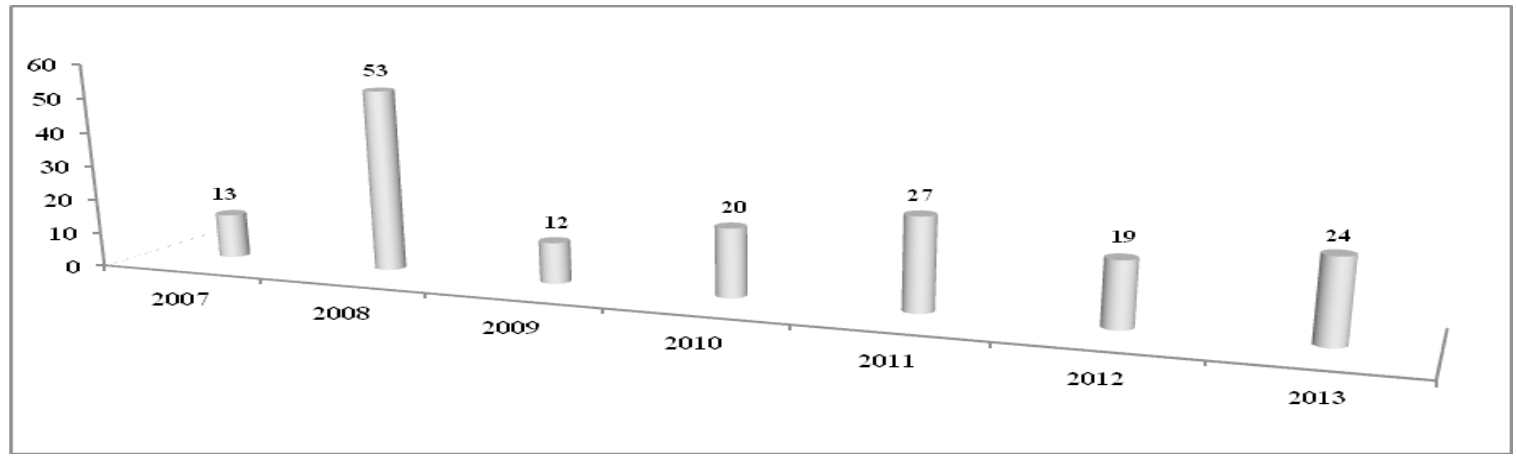

Fonte: CMCONSULTORIA (2012); KPMG (2013).

O maior número de aquisições e fusões no ensino superior do setor privado brasileiro esteve concentrado no ano de 2008 , com o número de 53 , ou aproximadamente $31,5 \%$, das 168 transações.

De acordo com os valores mostrados pela CMCONSULTORIA para os montantes globais gastos nas fusões e aquisições, de 2007 a 2013, no ensino superior do setor privado brasileiro, como mostra o Gráfico 5, esse último ano foi o que apresentou o maior índice, de aproximadamente $\mathrm{R} \$ 3,64$ bilhões. No total para o período, os investimentos chegaram a $\mathrm{R} \$ 10,457$ bilhões (sem correção monetária).

Gráfico 5: Valor total despendido nas fusões e aquisições para o ensino superior no setor privado brasileiro (2007-2013) - em R\$ milhões

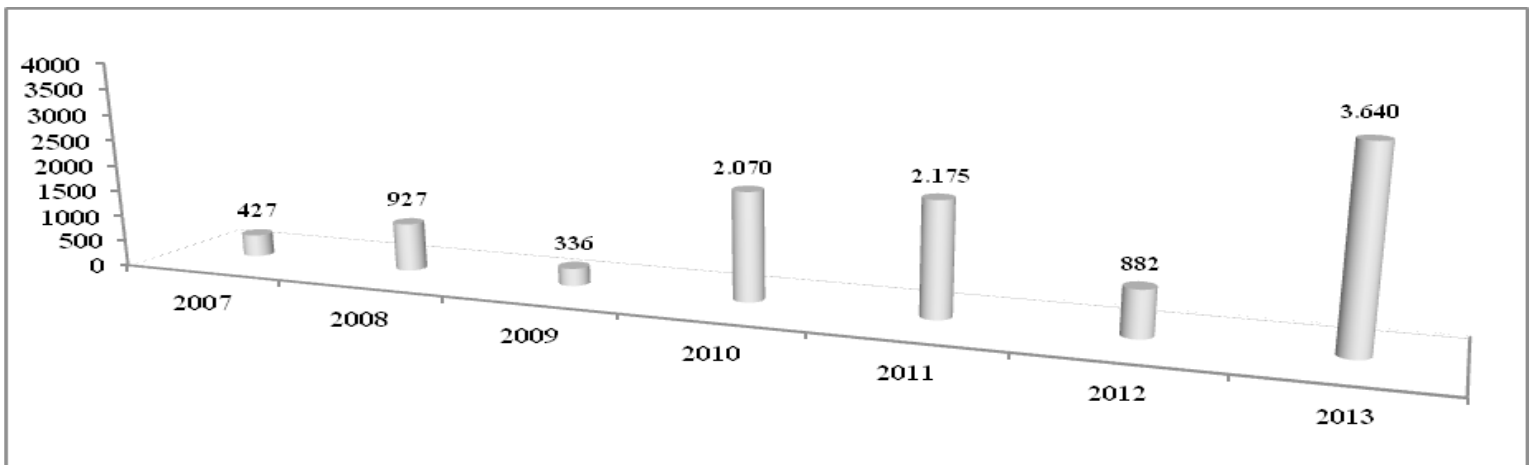

Fonte: CMCONSULTORIA (2012)

Os gastos com as aquisições e fusões no ensino superior do setor privado brasileiro cresceram aproximadamente $752,5 \%$, de 2007 a 2013. Para as IES particulares, no geral, o faturamento cresceu 29,6\%, quando passou de $\mathrm{R} \$ 24,7$ bilhões, em 2011, para um valor estimado de R\$ 32,0 bilhões, em 2013 (GUILHERME; GLENIA, 2013).

\footnotetext{
Os dados de 2008 a 2013 foram retirados da KPMG, enquanto o de 2007, da CMCONSULTORIA. Convém ressaltar que de 2008 a 2011 houve divergências nos números apresentados pelas fontes.
} 
Para as empresas de capital aberto, inclusive as educacionais, as estratégias na busca pela valorização das ações, em curto prazo, muitas vezes levam à sua recompra no mercado financeiro por parte das companhias; ao seu emprego como veículo de troca nas transações; ao enfraquecimento das regras contábeis, sobretudo pelas possibilidades de rápidas oscilações no mercado de capitais; e até mesmo à manipulação dos resultados financeiros ou, ainda, à criação de opções de compra ou à subscrição de ações para o favorecimento dos executivos e dos empregados.

Dessa forma, os CEO's podem administrar, por exemplo, uma empresa de ensino superior do setor privado, com finalidades lucrativas, sem muitos conhecimentos sobre a questão educacional propriamente dita, já que a educação é tratada como mais uma mercadoria (OLIVEIRA, 2009), com suas características específicas.

A comparação feita pelo economista Marcelo Cordeiro, que trabalhava na Fidúcia Asset Management na segunda metade dos anos 2000, e tinha como função buscar novos investimentos para o ensino superior do setor privado com finalidades lucrativas, citada por Erthal e Perozim (2007), estabeleceu um paralelo entre os supermercados e as IES, de forma que os primeiros poderiam vender produtos, a exemplo dos tomates, enquanto as segundas, um assento nas salas de aulas para os estudantes.

A Kroton Educacional S.A. surgiu como um curso pré-vestibular, na cidade de Belo Horizonte, Estado de Minas Gerais, em 1966. Depois de mais de três décadas, e de um importante crescimento na área do ensino básico, no começo dos anos 2000 , foi criada a primeira faculdade, denominada Pitágoras, em parceria com a Apollo International, que durou até 2005.

Em julho de 2007, a Kroton realizou o seu Initial Public Offering (IPO). Nos dados disponibilizados pela BM\&FBovespa, o valor captado com as ofertas primária e secundária, no mercado de balcão não organizado, chegou a aproximadamente $R$ \$ 478,8 milhões, por meio de 12.276.250 Units, ao preço de $\mathrm{R} \$ 39,0$ cada, as quais representaram uma ação ordinária e seis ações preferenciais.

Todo o processo ocorreu de acordo com as regras da legislação societária brasileira e com as internacionais (para a colocação de Units no exterior). A participação dos investidores estrangeiros foi de $\mathrm{R} \$ 336,1$ milhões $(70,2 \%$, em relação ao total); a dos investidores institucionais, $\mathrm{R} \$ 96,7$ milhões (20,2\%, em relação ao total); a de pessoas físicas, $\mathrm{R} \$ 44,0$ milhões $(9,2 \%$, em relação ao total); entre outros, no valor de $\mathrm{R} \$ 2,0$ milhões (0,4\%, em relação ao total) (KROTON EDUCACIONAL S.A., 2007).

Conforme a Kroton, o seu formato de ensino padronizado e replicável, subsidiado pela tecnologia da informação, que possibilita a articulação e a integração das partes, e ainda permite a composição de um modelo único de negócio, busca ganhos de produtividade (redução de custos e de despesas), de escala e de sinergia nas operações de mercado do ensino básico e do ensino superior.

Com um modelo de ensino superior ainda inicial, que a partir de 2007 teve forte expansão, a Kroton estruturou novas estratégias de marketing (publicidade, propaganda e assessoria de imprensa), para a divulgação de suas marcas em várias partes do país. Em 2008, a companhia ampliou a maturação das suas unidades de ensino, além da substituição operacional e acadêmica daquelas que foram adquiridas pelo modelo de gestão corporativa.

Ainda, citam-se as novas oportunidades de financiamento estudantil junto a instituições financeiras; a instalação do Centro de Serviços Compartilhados, tendo em vista a melhor eficiência nos processos de trabalho; bem como a recompra de ações para a outorga do plano de opções para os executivos, a ser concretizada em 2009; entre outros.

As informações de 2008 não divulgaram o número de funcionários demitidos pela Kroton, em função das adaptações nas unidades de ensino quanto às políticas de cargos e salários, o que promoveria "reflexos positivos no médio e longo prazo" (KROTON 
EDUCACIONAL S.A., 2009, p. 3), quer dizer, reduzindo os gastos e aumentando os lucros e o valor de mercado da companhia. O que foi disponibilizado consistiu nos custos de $R \$ 5,0$ milhões, referentes às rescisões trabalhistas.

No ano de 2009, para conseguir uma expansão sustentada, a companhia anunciou uma série de medidas que teriam de ser implantadas em curto e em longo prazo.

Para o primeiro, citam-se as novas estratégias de marketing para a captação de alunos; a desativação ou a venda de unidades de ensino que não apresentassem a rentabilidade esperada; a renegociação dos contratos mais importantes com os fornecedores; a reestruturação dos custos internos das unidades de ensino; a instalação de um orçamento matricial; a elevação dos critérios para a abertura de novos campi e a revisão dos seus mecanismos de apoio interno e a ampliação do número de parceiros para a oferta do crédito estudantil (KROTON EDUCACIONAL S.A., 2010).

Quanto ao segundo, o fortalecimento da gestão corporativa, a exemplo da contratação de novos executivos; o plano de opção de compra de ações, principalmente para os administradores da companhia; a instalação de uma gerência guiada por diretrizes; a ampliação do ensino a distância e os estudos detalhados sobre as possíveis empresas a serem adquiridas.

$\mathrm{Na}$ preocupação com a qualidade do ensino, a Kroton implantou currículos padronizados; criou disciplinas de ensino a distância em todos os cursos reconhecidos nas diversas faculdades da companhia; efetivou ciclos anuais de avaliação; instalou processos de auditoria acadêmica e melhorou a infraestrutura de laboratórios e do acervo bibliográfico.

Muitos desses pontos são bastante questionáveis quanto ao processo de formação dos indivíduos, com qualidade. Essa palavra, diante das dificuldades vinculadas ao entendimento e ao consenso sobre o que possa ser tido como qualificado nas questões sobre o ensino e a aprendizagem, passou a ser usada para se referir a quase tudo, já que a acumulação do capital vinha crescendo a passos largos, bem com o Estado brasileiro massivamente avalizou sua operacionalização, e começou a financiar parte importante desse processo.

Quase todo o ano de 2010, na Kroton, foi dedicado à sua reestruturação organizacional em virtude do forte impacto causado pela aquisição da IUNI Educacional. Assim, no terceiro trimestre do ano mencionado, a companhia inaugurou um novo Modelo Pedagógico para as sua unidades de ensino; unificou os sistemas de gestão acadêmicos, financeiros e o Centro de Serviços Compartilhados e integrou o processo de planejamento e o controle orçamentário.

$\mathrm{Na}$ busca pelo sucesso da integração entre as duas instituições e para diminuir os custos e as despesas nas unidades de ensino, a Kroton dispensou 1.079 funcionários, dos quais 449 docentes, e 630 do quadro administrativo.

O novo Modelo Pedagógico unificou os projetos e as grades curriculares de todos os cursos de graduação e, para 2011, a companhia já havia conseguido o credenciamento legal para a oferta de cursos de pós-graduação a distância.

Alternativa importante para o crescimento da companhia seria a adoção constante de novas estratégias eficientes de marketing para a captação de alunos, além do combate severo à inadimplência. Caso as unidades de ensino não apresentassem os ganhos de produtividade esperados, deveriam ser desativadas ou vendidas.

A Kroton encerrou o ano de 2011 com um destacado crescimento, proporcionado pelas novas aquisições realizadas no período. No mês de junho, a companhia realizou uma nova Oferta Pública de Ações, por meio da emissão de 20.552.200 Units, ao preço de $R \$ 19,25$ cada, o que gerou uma arrecadação bruta de aproximadamente $R \$ 395,6$ milhões. 
Depois de descontados os custos de $\mathrm{R} \$ 22,5$ milhões, a captação líquida atingiu $\mathrm{R} \$ 373,1$ milhões. Novamente, os investidores estrangeiros injetaram a maior parte do capital, com cerca de $\mathrm{R} \$ 275,7$ milhões $(69,7 \%$, do total); os investidores institucionais vieram em seguida, com $R \$ 83,5$ milhões $(21,1 \%$, do total); as pessoas físicas, com $R \$$ 35,6 milhões $(9,0 \%$, do total); enquanto outros investidores, com $R \$ 0,8$ milhão $(0,2 \%$, do total).

O preço médio das mensalidades chegou a aproximadamente $R \$ 543,3$, para o ensino superior presencial, no ano de 2012 , um crescimento de 5,6\% na comparação com 2011; no ensino superior a distância, a $R \$ 213,3$. Na graduação presencial, o valor foi de $\mathrm{R} \$ 581,9$, enquanto na pós-graduação presencial, de $\mathrm{R} \$ 200,4$. Para a graduação a distância, o preço atingiu $R \$ 225,2$; na pós-graduação a distância, $R \$ 108,8$ (KROTON EDUCACIONAL S.A., 2013).

Em 2012, a Kroton migrou para o Novo Mercado da BM\&FBovespa e todas as ações foram convertidas em ações ordinárias. Depois da conversão, acabaram agrupadas no montante de sete para um. Além disso, a companhia deixou de ter um bloco de controle, mas o Advent International ${ }^{9}$ (um dos maiores fundos de Private Equity do mundo) ainda era o principal acionista, com $10,2 \%$ das ações ordinárias. De todas as ações, $66,0 \%$ se encontravam em livre circulação no mercado acionário.

Alguns dados para a Kroton, operacionais e financeiros, de 2007 a 2012, permitem melhor entender o destacado crescimento pelo qual passou no período. No que tange ao número total de alunos, conforme o Gráfico 6, a expansão chegou a aproximadamente $2.178,4 \%$, ao sair de 17.997, no primeiro ano, para 410.035, no segundo.

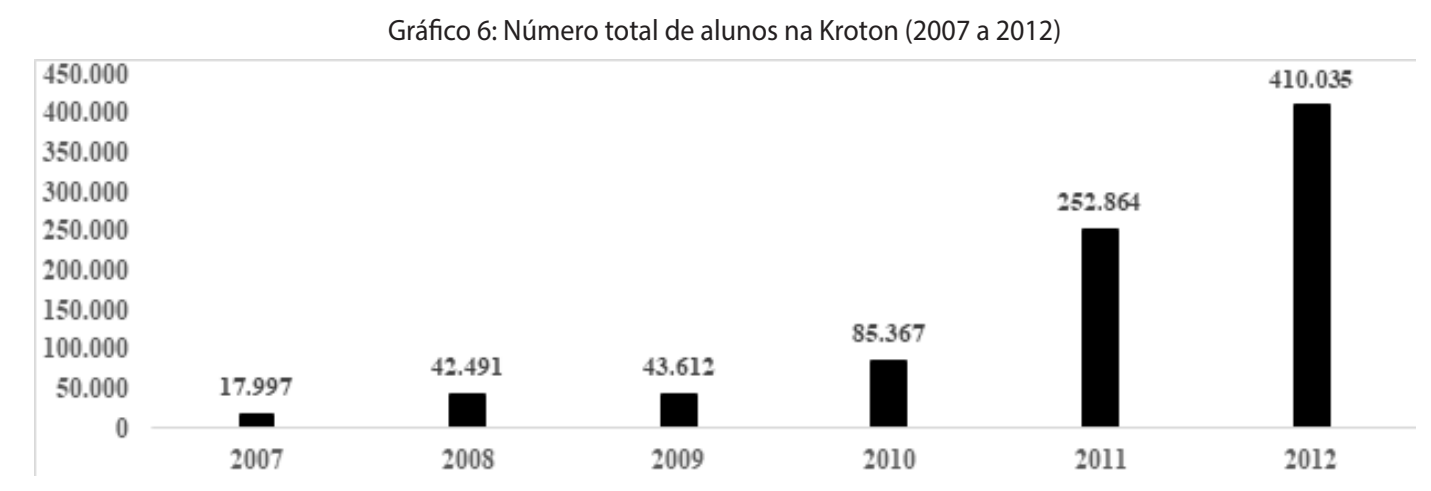

Fonte: Elaborado pelo autor.

Isso se deu, também, graças às aquisições feitas pela companhia ${ }^{10}$, sobretudo depois de 2011, particularmente por meio de IES com forte atuação no ensino a distância no Brasil, como se pode verificar no Gráfico 7.

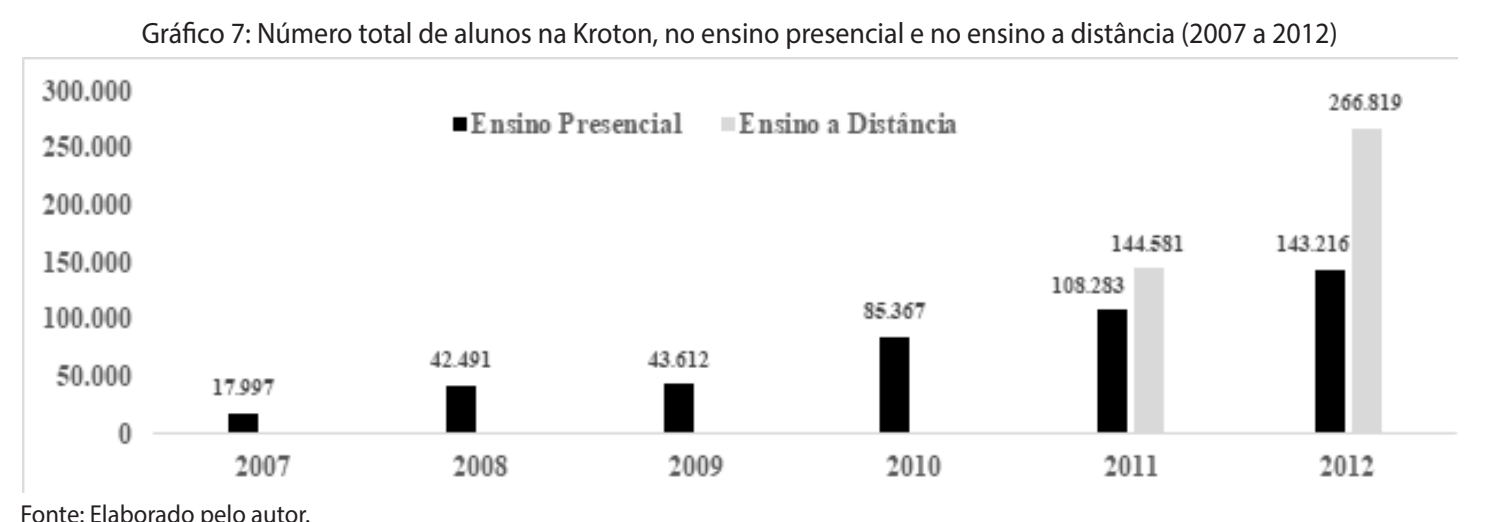

\footnotetext{
9 Esse Fundo, no ano de 2014, investia em mais de 280 empresas espalhadas por 36 países do planeta, e havia dado suporte para mais de 140 IPOs em bolsas de valores de várias nações (SGUISSARDI, 2014).

10 Com um processo de avaliação iniciado no ano de 2013, em 2014, o Conselho Administrativo de Defesa Econômica (CADE), aprovou a fusão da Kroton com a Anhanguera, mediante algumas restrições impostas às companhias, que passaram a ter um valor estimado de mercado em torno de $\mathrm{R} \$ 21,5$ bilhões, em maio de 2014, e cerca de 1,0 milhão de alunos. Em 2016, a Kroton e a Estácio anunciaram um acordo de fusão, mas esse não foi aprovado pelo CADE, em virtude da possível oligopolização no mercado de ensino superior no Brasil, tanto no presencial quanto a distância.
} 
Assim, o número de campi no ensino presencial obteve uma expansão aproximada de 217,6\%, quando saíram de 17 unidades de ensino, em 2007, para 54, em 2012. Já os polos no ensino a distância cresceram 12,0\%, de 2011 (ano inicial de atuação nessa modalidade de ensino pela companhia), para 2012, ao passar de 399, para 447.

Cabe aqui uma ressalva especial para o FIES, depois da série de modificações que sofreu, a partir de 2010, até 2014 (quando teve que receber um freio dos cofres públicos), em que o Fundo Público passou a determinar uma importante base de sustentação para a arrecadação financeira das empresas educacionais, particularmente para as grandes, com a garantia do pagamento das mensalidades para os estudantes.

Se, em 2011, o número de estudantes que contavam com o FIES, na Kroton, ficou na casa dos 20 mil, diante de um total de 253 mil, em 2014, os contemplados chegaram a 259 mil, num total de 987 mil alunos (MALVESSI, 2017).

Ou seja, em termos percentuais, isso significa que a proporção de estudantes matriculados com o FIES, na Kroton, subiu de aproximadamente 7,9\%, em relação ao total, para 26,2\%, de 2011, para 2014. Quando incorporamos as bolsas do PROUNI nessa estatística, algo em torno de $30 \%$ a $40 \%$ de sua receita bruta teria sido gerada com os recursos públicos.

Em 2013, de acordo com Burgarelli (2017, p. 42), "mais de cem instituições tinham mais de $60 \%$ dos estudantes com mensalidades financiadas pelo governo na base de matrículas", muitas delas com cursos que apresentaram conceitos insatisfatórios nos exames realizados pelo SINAES.

Quando se pensa que a taxa de escolarização líquida no ensino superior do país, saiu de $7,4 \%$, em 1999, para $18,1 \%$, em 2015 , bem longe do que propunha o PNE/200111, em alcançar $30 \%$, pode-se perceber por onde foi se dando, de forma expressiva, esse crescimento, apenas tomando como exemplo a Kroton, que se constituiu como a maior empresa educacional, não só do Brasil, mas do planeta.

O montante de recursos arrecadados sobre o capital próprio da Kroton, o que envolveu as Ofertas Públicas de Ações (incluindo o IPO), além da emissão de debêntures, atingiu aproximadamente $\mathrm{R} \$ 1,4$ bilhão, os quais foram gastos principalmente nas aquisições, na expansão e nas melhorias das unidades de ensino existentes. As aquisições chegaram ao total de 19, de 2007 a 2012, e os recursos financeiros investidos pela companhia alcançaram aproximadamente $\mathrm{R} \$ 2,3$ bilhões, com 324,7 mil estudantes envolvidos nas transações.

Determinados dados financeiros permitem melhor entender os efeitos do crescimento na Kroton, de 2007 a 2012. A Receita Bruta e a Receita Líquida, conforme o Gráfico 8, demonstraram um aumento aproximado de respectivamente $1.863,9 \%$ e $1.632,1 \%$, ou seja, passaram de $\mathrm{R} \$ 79,3$ milhões, para $\mathrm{R} \$ 1.557,4$ milhões, na primeira, e de $\mathrm{R} \$ 72,6$ milhões, para R\$1.257,5 milhões, na segunda.

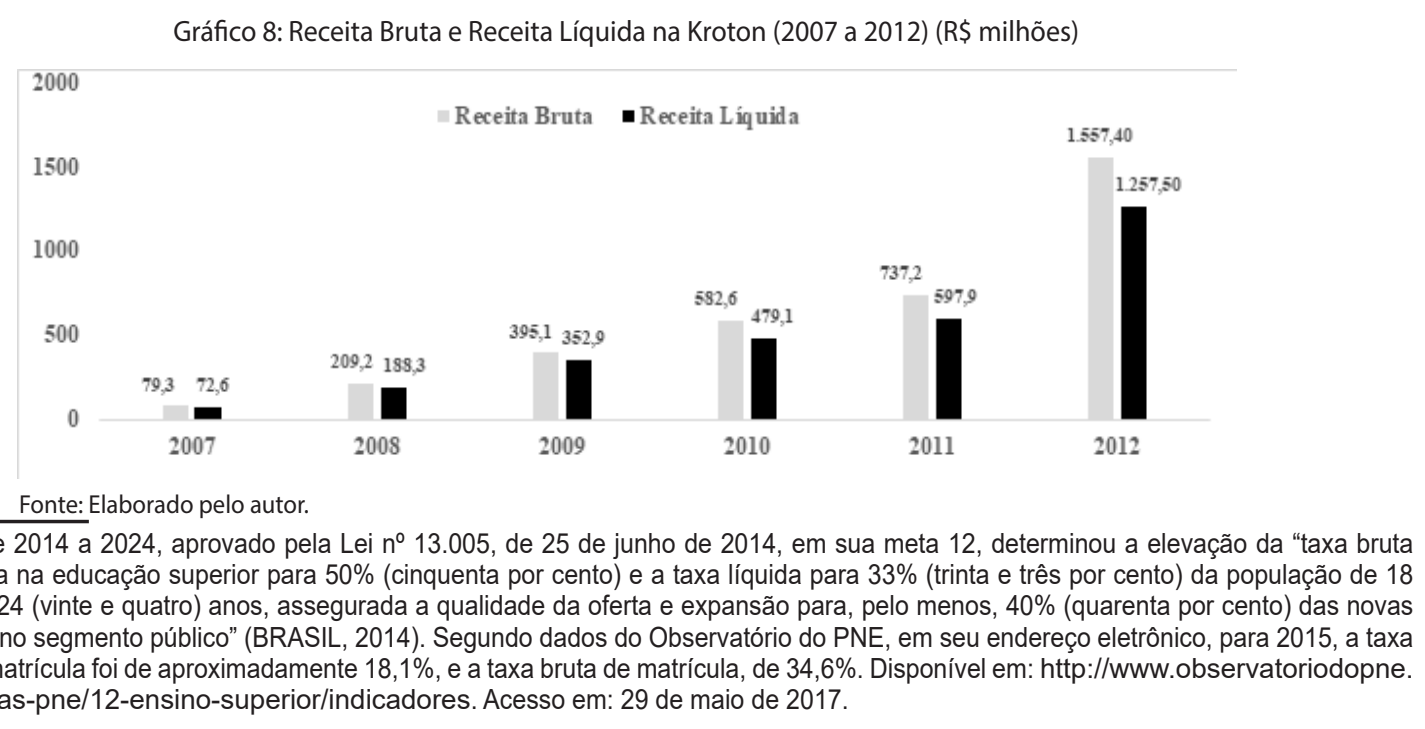


O Lucro Bruto e o Lucro Líquido também obtiveram importante crescimento, de 2007 a 2012, apesar das oscilações, inclusive com os resultados negativos, para esse último, como mostra o Gráfico 9.

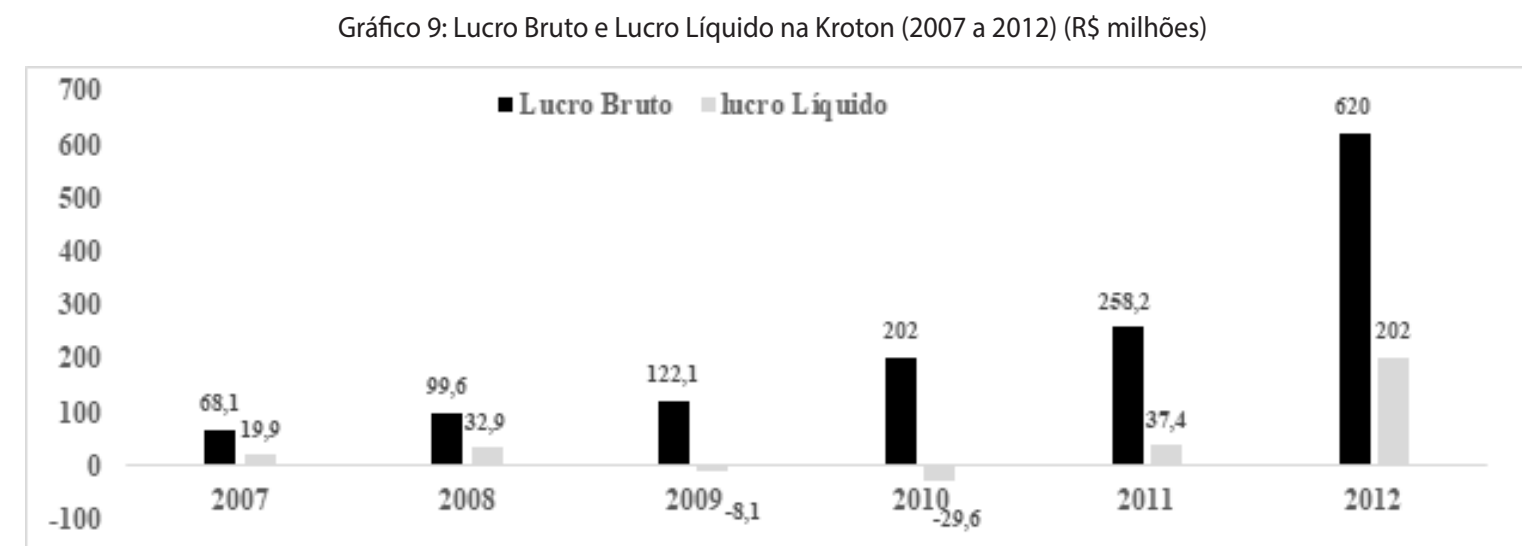

Fonte: Elaborado pelo autor.

Para o primeiro, a expansão aproximada chegou a $810,4 \%$, ou seja, saiu de $R \$$ 68,1 milhões, no primeiro ano, para $\mathrm{R} \$ 620,0$, no segundo. Com relação ao segundo, o aumento foi de $50.400 \%$, pois passou de $\mathrm{R} \$ 0,4$ milhão, para $\mathrm{R} \$ 620,0$ milhões. Por fim, o Patrimônio Líquido da Kroton, de 2007 a 2012, conseguiu um aumento aproximado de $404,9 \%$ quando saiu de $\mathrm{R} \$ 437,5$ milhões, no primeiro ano, para $\mathrm{R} \$ 2.209,1$ milhões, no segundo, conforme o Gráfico 10.

Gráfico 10: Patrimônio Líquido para a Kroton (2007 a 2012) (R\$ milhões)

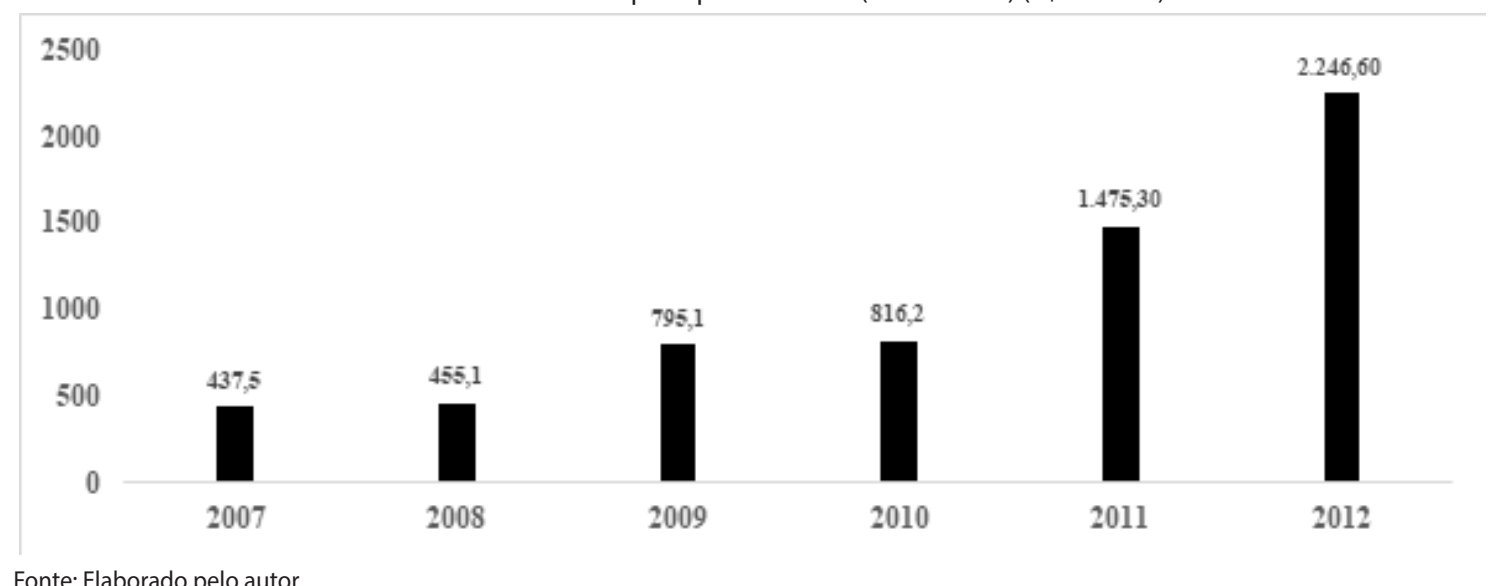

Ainda, o valor de mercado da companhia no último ano atingiu $\mathrm{R} \$ 6,4$ bilhões. Não só a kroton, mas o setor educação na Bovespa se constituiu como um dos mais lucrativos, no mercado de ações no país, com importante participação de fundos de investimentos, estrangeiros e nacionais. Em 2012, a Kroton tinha como principal acionista um grande fundo de Private Equity, cuja atuação se dava em várias partes do planeta.

Apenas pelos dados da Kroton, pode-se perceber a tendência de oligopolização no ensino superior do setor privado, o que tenderá a aumentar nos próximos anos, na busca pela acumulação de capital e maximização dos lucros. Em seguida, algumas das principais conclusões e contribuições do trabalho.

\section{CONSIDERAÇÕES FINAIS}

O ensino superior do setor privado no Brasil, em especial aquele com finalidades lucrativas, nas quase duas últimas décadas, passou por um destacado crescimento, graças a fatores diversos, tais como o forte incentivo, legal e financeiro, dos Poderes Públicos, ou as poucas melhorias na distribuição de renda que foram verificadas recentemente no conjunto populacional. 
Dessa forma, a profissionalização da gestão empresarial (em rígida parceria com fundos de equidade privada, sobretudo estrangeiros) das grandes empresas educacionais no Brasil, transformou-se no ponto central para as suas administrações, a fim de buscar a consolidação da marca em variadas regiões do território nacional, e de criar o constante aumento de valor para os ativos das companhias (em especial no mercado acionário), no intuito de elevar a acumulação de capital.

Para aumentar as suas margens de lucro, a Kroton se submeteu a um intenso processo de integração da gestão empresarial e acadêmica nas suas unidades de ensino, espalhadas pelo país, o que para a companhia foi colocado como sinônimo de qualidade na gestão corporativa e educacional.

A empresa apostou na parceria com os fundos de investimentos estrangeiros; na reestruturação da gestão empresarial, com a redução dos custos; na crescente sustentação do Fundo Público, por meio do FIES e do PROUNI; bem como na aquisição de grandes empresas de ensino superior a distância, como a UNOPAR e a UNIASSELVI ${ }^{12}$.

O próximo passo se deu em direção à fusão com as principais concorrentes do setor, primeiro com a Anhanguera, o que ocorreu definitivamente em 2014; e posteriormente com a Estácio de Sá, cuja proposta foi recusada pelo CADE. Com isso, a oligopolização, principalmente das matrículas no ensino superior privado do país, tem avançado a passos largos, com fraca regulamentação por parte das instituições públicas.

A agressiva estratégia de gestão empresarial da Kroton chama a atenção no contexto econômico atual. Por alguns anos, recentes, o setor de educação, constituído pela BM\&FBovespa, liderou os índices de lucratividade da bolsa. Com a segurança do FIES, depois de 2010, a rentabilidade das ações da companhia, por exemplo, de 2012 a 2014 , ultrapassou a casa dos $300 \%$, muito acima da inflação no período.

Quando o FIES passou por modificações, com a perspectiva de redução nos gastos financeiros, no final de 2014, de imediato as ações da companhia na bolsa sofreram os efeitos das transformações, com sua desvalorização, também em curto prazo.

Os dados apresentados permitiram observar um destacado crescimento nas receitas operacionais e financeiras da Kroton, de 2007 a 2012, já que, como muitas das grandes corporações financeiras, o principal objetivo da companhia passou a ser a sua valorização em curto prazo, o que acaba por reforçar e ampliar os laços entre educação e mercadoria.

\section{REFERÊNCIAS}

BARREYRO, G. B.; ROTHEN, J. C. Avaliação da educação superior como política pública. In: ROTHEN, J. C.; BARREYRO, G. B.. (Orgs.). Avaliação da educação: diferentes abordagens críticas. São Paulo: Xamã, 2011, p 75-87.

BRASIL. Constituição da República Federativa do Brasil de 1988. Diário Oficial da União. Brasília, DF, 1988, 413p.

Lei $n^{\circ}$ 9.394, de 20 de dezembro de 1996. Estabelece as diretrizes e bases da educação nacional. Diário Oficial da União. Brasília, DF, 1996.

Decreto $n^{\circ} 2.207$, de 15 de abril de 1997. Regulamenta, para o Sistema Federal de

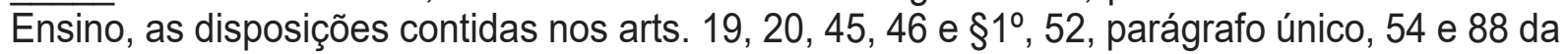
Lei $n^{\circ}$ 9.394, de 20 de dezembro de 1996, e dá outras providências. Diário Oficial da União. Brasília, DF, 1997a.

\footnotetext{
12 Que foi vendida, depois da fusão com a Anhanguera, em 2014, como uma das condições impostas pelo CADE, para o grupo Vinci Capital Gestora de Recursos, BRL Trust Investimentos e TCG Gestor (subsidiária do Fundo de Equidade Privada Carlyle, com sede em Washington D.C., com filiais em diversas partes do planeta), por um valor que poderia chegar a até $R \$ 1,105$ bilhão. Disponível em: http://www1.folha. uol.com.br/mercado/2015/10/1698592-kroton-vende-uniasselvi-para-fundos-por-r-1105-bilhao.shtml; Acesso em: 20 de junho de 2016.
} 
Decreto $n^{\circ} 2.306$, de 19 de agosto de 1997. Regulamenta, para o Sistema Federal de Ensino, as disposições contidas no art. 10 da Medida Provisória $\mathrm{n}^{\circ} 1.477-39$, de 8 de agosto de 1997, e nos arts. 16, 19, 20, 45, 46 e $\S 1^{\circ}, 52$, parágrafo único, 54 e 88 da Lei $n^{0} 9.394$, de 20 de dezembro de 1996, e dá outras providências. Diário Oficial da União. Brasília, DF, $1997 b$.

Instituto Nacional de Estudos e Pesquisas Educacionais Anísio Teixeira. Sinopse Estatística da Educação Superior (1999). Brasília, DF, 2000.

. Lei no 10.172, de 9 de janeiro de 2001. Aprova o Plano Nacional de Educação e dá outras providências. Diário Oficial da União. Brasília, DF, 2001a.

Decreto $n^{\circ} 3.860$, de 9 de julho de 2001. Dispõe sobre a organização do ensino superior, a avaliação de cursos e instituições, e dá outras providências. Diário Oficial da União. Brasília, DF, 2001b.

Lei $n^{0} 10.260$, de 12 de julho de 2001. Dispõe sobre o Fundo de Financiamento ao estudante do Ensino Superior e dá outras providências. Diário Oficial da União. Brasília, DF, 2001c.

Instituto Nacional de Estudos e Pesquisas Educacionais Anísio Teixeira. Sinopse Estatística da Educação Superior (2000). Brasília, DF, 2001d.

. Lei no 10.861, de 14 de abril de 2004. Institui o Sistema Nacional de Avaliação da Educação Superior - SINAES. Diário Oficial da União. Brasília, DF, 2004.

Instituto Nacional de Estudos e Pesquisas Educacionais Anísio Teixeira. Sinopse Estatística da Educação Superior (2004). Brasília, DF, 2005a.

Lei $n^{0}$ 11.096, de 13 de janeiro 2005. Institui o Programa Universidade para Todos PROUNI, regula a atuação de entidades beneficentes de assistência social no ensino superior; altera a Lei $n^{0} 10.891$, de 9 de julho de 2004, e dá outras providências. Diário Oficial da União. Brasília, DF, 2005b.

. Decreto $n^{\circ}$ 5.622, de 19 de dezembro de 2005. Regulamenta o art. 80 da Lei no 9.394, de 20 de dezembro de 1996, que estabelece as diretrizes e bases da educação nacional. Diário Oficial da União. Brasília, DF, 2005c.

. Decreto $n^{0} 5.773$, de 9 de maio de 2006. Dispõe sobre o exercício das funções de regulação, supervisão e avaliação de instituições de educação superior e cursos superiores de graduação e sequenciais no sistema federal de ensino. Diário Oficial da União. Brasília, DF, 2006.

. Instituto Nacional de Estudos e Pesquisas Educacionais Anísio Teixeira. Sinopse Esta$\overline{\text { tística }}$ da Educação Superior (2009). Brasília, DF, 2010.

Lei no 13.005, de 25 de junho 2014. Aprova o Plano Nacional de Educação e dá outras providências. Diário Oficial da União. Brasília, DF, 2014.

BURGARELLI, R. Explosão e implosão do FIES: como o ensino superior privado virou centro dos gastos com educação do governo federal. In: MARINGONI, Gilberto. O negócio da educação: aventuras na terra do capitalismo sem risco. São Paulo: FEPESP, 2017, p. 37-54.

CARVALHO, C. H. A. de. A política pública para a educação superior no Brasil (1995-2008): ruptura e/ou continuidade? 457p. Tese (Curso de Pós-Graduação em Ciências Econômicas) Universidade Estadual de Campinas, Campinas, 2011. 
CATANI, A. M.; HEY, A. P.; GILIOLI, R. S. P. PROUNI: democratização do acesso às Instituições de Ensino Superior? Educ. rev., n. 28, Curitiba, jul./dez.2006, p.125-140. Disponível em: <http://dx.doi.org/10.1590/S0104-40602006000200009>. Acesso: 07 ago. 2012.

CHAVES, V. L. J. Expansão da privatização/mercantilização do ensino superior brasileiro: a formação dos oligopólios. Educ. Soc., vol. 31, no 111, Campinas, abr./jun. 2010, p. 481-500. Disponível em: <http://dx.doi.org/10.1590/S0101-73302010000200010>. Acesso em: 20 set. 2012.

CHESNAIS, F.. A mundialização do capital. Trad. S. F. Foá. São Paulo: Xamã, 1996, 335p.

CMCONSULTORIA. Fusões e aquisições no ensino superior: análise do cenário 2007 a 2011. 2012. Disponivel em: <www.cmconsultoria.com.br/arquivos/ResumoAquisicoesIES. pdf>. Acesso em: 10 jan. 2013.

COSTA, F. L. O. Financeirização do capital no ensino superior privado com fins lucrativos no Brasil (2007-2012). 367p. Tese (Curso de Pós-Graduação em Educação) - Universidade de São Paulo, São Paulo, 2016.

CUNHA, L. A.. O desenvolvimento meandroso da educação brasileira entre o estado e o mercado. Educ. Soc., vol. 28, n 100, Campinas, oct. 2007, p. 809-829. Disponível em: <http:// dx.doi.org/10.1590/S0101-73302007000300009>. Acesso: 07 abr. 2013.

ERTHAL, J. M; PEROZIM, L. O ensino vai à Bolsa. Carta Capital, edição n 466.14 out. 2007. Disponível em: <http://www.cmconsultoria.com.br/vercmnews.php?codigo=28147>. Acesso em: 27 mai. 2014.

GUILHERME, P; GLENIA, F. Faturamento de faculdades privadas cresce $30 \%$ em 2 anos, estima estudo. iG, 2013. Disponível em: <http://g1.globo.com/educacao/noticia/2013/08/faturamento-defaculdades-privadas-cresce-30-em-2-anos-estima-estudo.html>. Acesso: 16 mai. 2014.

GUTTMANN, R. Uma introdução ao capitalismo dirigido pelas finanças. Novos estud. CEBRAP, São Paulo, no 82: novembro 2008, p. 11-33. Disponível em: <http://www.scielo.br/ scielo.php?pid=S0101-33002008000300001\&script=sci_arttext>. Acesso em: 31 mar. 2013.

KPMG. Pesquisa de fusões e aquisições. 2013. Disponível em: <https://www.kpmg.com/br>. Acesso em: 10 abr. 2014.

KROTON EDUCACIONAL S.A. Prospecto definitivo de distribuição pública primária e secundária de certificados de depósito de ações ("Units") de emissão da Kroton Educacional S.A. 19 jul. 2007, 623p. Disponível em: <http://www.kroton.com.br/ri/>. Acesso: 29 mai. 2014.

Divulgação dos resultados de 2008. 2009, 28p. Disponível em: <http://www.kroton. $\overline{c o m}$. br/ri/>. Acesso: 29 mai. 2014.

. Divulgação dos resultados de 2009. 2010, 32p. Disponível em: <http://www.kroton. com.br/ri/>. Acesso: 29 mai. 2014.

. Resultados para o 4T de 2012. 2013c, 36p. Disponível em: <http://www.kroton.com. $\overline{\mathrm{br} / \mathrm{ri} />}$. Acesso: 29 mai. 2014.

MALVESSI, O. Análise econômico-financeira de empresas do setor de educação. In: MARINGONI, G. O negócio da educação: aventuras na terra do capitalismo sem risco. São Paulo: FEPESP, 2017, p. 75-104.

MORETTI, D. M. A compatibilidade entre a lógica econômica e o ensino superior, após a Constituição Federal de 1988: o caso da Anhanguera Educacional Participações S.A.. 395p. 
Dissertação (Curso de Pós-Graduação em Direito) - Universidade de São Paulo, São Paulo, 2013.

NEVES, L. M. W. Legislação e planejamento no processo de privatização da educação superior. In: NEVES, L. M. W. (Org.). O empresariamento da educação: novos contornos do ensino superior no Brasil dos anos 1990. São Paulo: Xamã, 2002, p 137-150.

OLIVEIRA, R. P. A Transformação da Educação em Mercadoria no Brasil. Educ. Soc., Campinas, vol. 30, n. 108, p. 739-760, out. 2009. Disponível em: <http://dx.doi.org/10.1590/S010173302009000300006>. Acesso em: 17 nov. 2010.

A financeirização da economia e suas consequências para a educação superior no Brasil. In: MARINGONI, Gilberto. O negócio da educação: aventuras na terra do capitalismo sem risco. São Paulo: FEPESP, 2017, p. 27-35.

PLIHON, D. Desequilíbrios mundiais e instabilidade financeira. (A responsabilidade das políticas liberais: um ponto de vista keynesiano). Econ. e Soc., (7): 85-127, Campinas, dez.1996. Disponível em: <www.eco.unicamp.br/docprod/downarq.php?id=451\&tp=a>. Acesso: 20 nov. 2012.

POLIZEL, C.; STEINBERG, H. Governança corporativa na educação superior: casos práticos de instituições privadas (com e sem fins lucrativos). São Paulo: Saraiva, 2013, 146p.

SAVIANI, D. Escola e democracia. Campinas, SP: Autores Associados, 2008, 112p.

SEVERINO, A. José. A pesquisa em educação: a abordagem crítico-dialética e suas implicações na formação do educador. Contrapontos, ano 1, n 1, Itajaí, jan./jun. 2001, p. 11-22. Disponível em: <http://www6.univali.br/seer/index.php/rc/article/view/14/6>. Acesso: 11 jul. 2014.

SGUISSARDI, V. Universidade brasileira no século XXI: desafios do presente. São Paulo: Cortez, 2009, 341p.

. Estudo diagnóstico da política de expansão da(e acesso à) educação superior no Brasil (2002-2012). Brasília: Conselho Nacional de Educação, 2014 (mimeo), 191p. 